\title{
Anisopodidae and Dixidae (Diptera) of the Gemer region, with a new record for Slovakia
}

Anisopodidae and Dixidae (Diptera) of the Gemer region, with a new record for Slovakia. - Čas. Slez. Muz. Opava (A), 60: 181-184, 2011.

A b s t r a c t: Four species of Anisopodidae and two species of Dixidae are recorded from the Gemer region in central Slovakia. The material was obtained mainly in the years 2008-2011 by means of Malaise traps and by individual collecting by the author. One species, Sylvicola stackelbergi Krivosheina \& Menzel, 1998, is recorded from Slovakia for the first time.

K e y w o r d s: Insecta, Diptera, wood gnats, meniscus midges, new record, faunistics, Slovakia, Europe

\section{Introduction}

Wood gnats (Anisopodidae) and meniscus midges (Dixidae) are relatively small families of Diptera, with only about 158 and 185 described species in the world (Pape et al. 2009). Nine species of Anisopodidae and about 30 species of Dixidae are known to occur in Europe (de Jong 2007, Wagner 2007). The adults of Anisopodidae occur mainly in forest habitats, but sometimes also in gardens or on windows in houses. The larvae are found in various decaying organic materials such as the stems and roots of umbelliferous plants (Hancock 1989). The commonest species Sylvicola cinctus has also been reared from fungi (e.g. Ševčík 2010), frequently from sap flows from trees and on one occasion from a sheep carcase (Hancock 1990). The larvae of Dixidae are aquatic, living in running (Dixa Meigen, 1818) or stagnant waters (Dixella Dyar \& Shannon, 1924). The adults are usually found near the larval habitat.

A total of 6 species of Anisopodidae and 10 species of Dixidae are currently known to occur in Slovakia (Ševčík 2009b, Ševčík \& Halgoš 2009). The fauna of the Dixidae in Slovakia is, however, still inadequately known as no specific faunistic research has been carried out there up to the present and some records from Slovakia are based only on the identification of the larvae.

Four species of Anisopodidae and two species of Dixidae have been found in the Gemer region up to now and several additional species will undoubtedly be found there in the future.

\section{Material and methods}

The list of species below is based mainly on the material collected recently $(2008-2011)$ by the author in the Gemer region (considered here to cover the territory of three national parks in central Slovakia - Muránska planina, Slovenský raj and Slovenský kras) by means of Malaise traps and sweep netting, identified by the author and deposited in JSOC and SMOC. Most of the material presented in this paper was collected in the frame of the All Taxa Biodiversity Inventories project (ATBI, see www.atbi.eu) organized by Workpackage 7 (WP7) of the "European Distributed Institute of Taxonomy" (EDIT, see www.e-taxonomy.eu). For further details about methods and localities, including photographs, see Ševčík \& Kurina (2011). The nomenclature used here follows the Fauna Europaea database.

Abbreviations: * = new record for Slovakia, NP $=$ National Park, NPP $=$ National Nature Monument, NPR = National Nature Reserve, PR = Nature Reserve, $m=$ male, $f=$ female, JŠ = Jan Ševč́k leg., MT = Malaise trap, $\mathrm{JSOC}=\mathrm{Jan}$ Ševčík, Ostrava (personal collection), SMOC = Slezské zemské muzeum, Opava, Czech Republic.

\section{Survey of species}

\section{ANISOPODIDAE}

\section{*Sylvicola (Anisopus) stackelbergi Krivosheina \& Menzel, 1998}

This species was described by Krivosheina \& Menzel (1998) from northern Russia and subsequently recorded from Sweden, the Netherlands and Estonia (Kurina 2006). This is the first record from Slovakia, as well as from central Europe.

Locality: NP Muránska planina, NPR Hrdzavá, 28.vi.-26.vii.2010, 1 m, MT (JŠ). 
Sylvicola (A.) punctatus (Fabricius, 1787)

A rather common Holarctic species. Recently recorded from Slovakia (Pol’ana Mts) by Ševčík (2009a).

Localities: NP Muránska planina, NPR Hrdzavá, 28.vi.-26.vii.2010, 1 m, MT (JŠ); NP Slovenský kras, NPR Zádielská tiesňava, 30.viii.1980, 1 m, 15.vi.1981, 2 f(J. Roháček leg., at light).

\section{Sylvicola (Sylvicola) cinctus (Fabricius, 1787)}

A common and widely distributed Palaearctic species formerly confused with the less common $S$. fenestralis (Scopoli, 1763). Ševč́́k (2004, 2009a) recorded S. cinctus from several localities in Slovakia.

Localities: NP Muránska planina: NPR Cigánka, 930 m, 4.ix.2008, 1m; NPR Hrdzavá, 28.vi.-26.vii.2010, 1 m, MT; PR Fabova Hola, 1230 m, 15.v.-16.vi.2009, 1 m, MT (both JŠ); Dolina Hronca, 6.ix.2008, 4 m; NPR Poludnica, Maretkiná, 960 m, 16.v.2009, 1f ; NPR Poludnica, Suchý dol, 8.ix.2011, 2 f; Tisovec, along Furmanec brook, 12.vii.2011, 1 m, 1 f; NP Slovenský kras, NPR Zádielská tiesňava, 480 m, 5.ix.2008, $1 \mathrm{f}$ (all JŠ, sweeping).

\section{Sylvicola (S.) limpidus (Edwards, 1923)}

A rare montane species, included in the "Red book of Diptera of the Czech Republic" (Ševčík 2005) as a vulnerable species. In Slovakia, it is known also from Poloniny NP, Tatra Mts (both JŠ, unpubl.) and Pol'ana Mts (Ševč́́k 2009a).

Localities: NP Muránska planina, PR Fabova Hola, 1230m, 15.v.2009, 2 m, MT (JŠ).

\section{DIXIDAE}

\section{Dixa puberula Loew, 1849}

A locally common Palaearctic species, usually found along mountain streams. From Slovakia (Polana Mts) recently recorded by Ševč́k (2009a).

Localities: NP Muránska planina: Dolina Dudlavky, 820 m, 6.ix.2008, 2 m; NPR Hrdzavá, 520 m, 1.xi.2008, 2 m, 14.v.2009, 6 m; NPR Poludnica, Suchý dol, 8.ix.2011, $1 \mathrm{~m}$; Tisovec, along Furmanec brook, 12.vii.2011, 6 m; NP Slovenský kras: NPR Zádielská tiesňava, 480 m, 5.ix.2008, 4 m, 31.x.2008, 1m (all JŠ, sweeping).

\section{Dixa submaculata Edwards, 1920}

A rather common and widespread European species. Recently recorded from Slovakia by Martinovský (1995) and Ševč́k (2009a).

Localities: NP Muránska planina: Dolina Hronca, 760 m, 6.ix.2008, 2 m; NPR Javorníková, $680 \mathrm{~m}$ 14.v.2009, 1 m; NPR Hrdzavá, 520 m, 3.ix.2008, 3 m, 1.v.2010, 1 m; Tisovec, along Furmanec brook, 12.vii.2011, $1 \mathrm{~m}$ (all JŠ, sweeping).

Acknowledgements: I am grateful to the administration of the ATBI-Gemer project, particularly to Katarína Necpálová and Eduard Stloukal, and to the staff of the Administration of the Muránska planina NP for their help and hospitality during my study visits to the area. This paper was also partly supported by the Czech Science Foundation (grant No. 206/08/1500) and by the IGS 201103 grant of the Silesian Museum in Opava.

\section{References}

Hancock E.G. (1989): Notes on the window gnats, genus Sylvicola (Diptera; Anisopodidae), in Scotland. Scottish Naturalist, 1989: 3-13.

- (1990): Sylvicola cinctus (F.) (Dipt., Anisopodidae) as a carrion feeder. Entomologist's monthly Magazine, 126: 50 .

Jong H. de (2007): Fauna Europaea: Anisopodidae. In Jong H. de (ed.): Fauna Europaea: Diptera, Nematocera. Fauna Europaea Version 1.3. <http://www.faunaeur.org>.

Krivosheina N. P. \& Menzel F. (1998): The Palaearctic species of the genus Sylvicola Harris, 1776 (Diptera, Anisopodidae). Beiträge zur Entomologie, 48 (1): 201-217.

Kurina O. (2006): A review of Estonian wood gnats (Diptera: Anisopodidae). Sahlbergia, 11: 18-22.

Martinovský J. (1995): Dixidae, p. 43. In Roháček J., Starý J., Martinovský J. \& Vála M. (eds): Diptera Bukovských vrchov. Diptera of the Bukovské hills. Humenné, 232 pp.

Pape T., Bickel D. \& Meier R. (2009): Diptera Diversity. Status, Challenges and Tools. Brill, Leiden. 459 pp.

Ševčík J. (2004): Faunistic records from the Czech and Slovak Republics: Diptera. Anisopodidae. Folia Facultatis Scientiarum Naturalium Universitatis Masarykianae Brunensis, Biologia, 109: 323-324.

- (2005): Anisopodidae, Mycetobiidae, pp. 262-263. In: Farkač J., Král D. \& Škorpík M. (eds.): Červený seznam ohrožených druhů České republiky. Bezobratlí. Red list of threatened species in the Czech Republic. Invertebrates. Agentura ochrany př́rody a krajiny ČR, Praha, 760 pp (in Czech and English). 

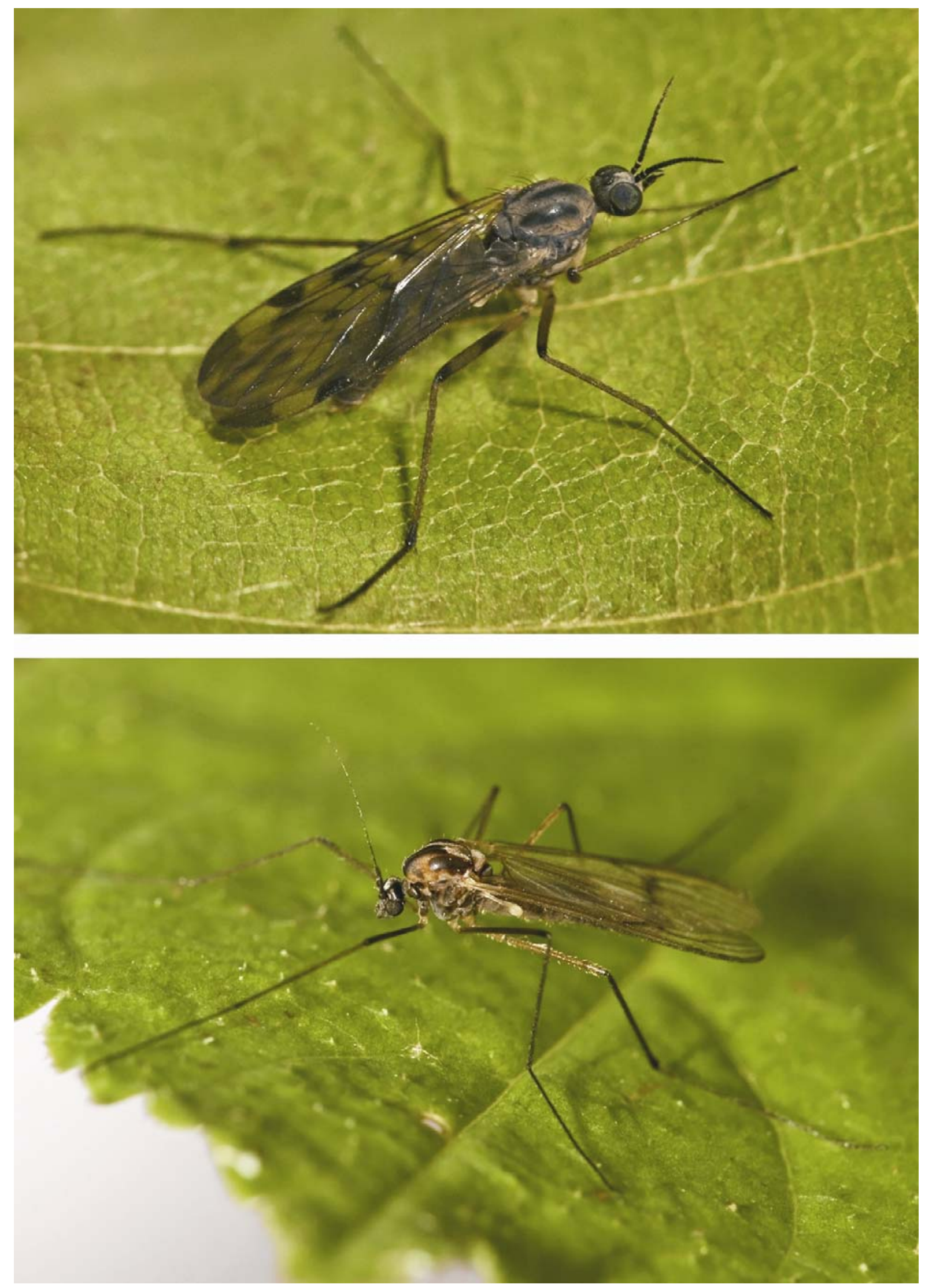

Figs. 1 and 2: 1 - Female of Sylvicola cinctus; 2 - Male of Dixa puberula (photos by J. Ševčík, both specimens are from NP Muránska planina). 
- (2009a): Anisopodidae (p. 93), Dixidae (p. 99). In Roháček J. \& Ševčík J. (eds): Diptera of the Pol’ana Protected Landscape Area - Biosphere Reserve (Central Slovakia). Zvolen. 340 pp.

- (2009b): Anisopodidae Edwards, 1921. In Jedlička L., Kúdela M. \& Stloukalová V. (eds): Checklist of Diptera of the Czech Republic and Slovakia. Electronic version 2. $<$ http://zoology.fns.uniba.sk/diptera2009 $>$ + CD-ROM: ISBN 978-80-969629-4-5.

- (2010): Czech and Slovak Diptera associated with fungi. Slezské zemské muzeum, Opava. 112 pp.

Ševčík J. \& Halgoš J. (2009): Dixidae Schiner, 1868. In Jedlička L., Kúdela M. \& Stloukalová V. (eds): Checklist of Diptera of the Czech Republic and Slovakia. Electronic version 2. $<$ http://zoology.fns.uniba.sk/diptera2009> + CD-ROM: ISBN 978-80-969629-4-5.

Ševčík J. \& Kurina O. (2011): Fungus gnats (Diptera: Sciaroidea) of the Gemer region (Central Slovakia): Part 1 - Bolitophilidae, Diadocidiidae, Ditomyiidae and Keroplatidae. - Čas. Slez. Muz. Opava (A), 60: 1123.

Wagner R. (2007): Fauna Europaea: Dixidae. In Jong H. de (ed.): Fauna Europaea: Diptera, Nematocera. Fauna Europaea version 1.3. <http://www.faunaeur.org $>$.

Author's address: Jan Ševčík, University of Ostrava, Chittussiho 10, CZ-710 00 Ostrava \& Silesian Museum, Tyršova 1, CZ-746 01 Opava, Czech Republic. E-mail: sevcikjan@hotmail.com 